OPEN ACCESS

Edited by:

Simona W. Rossi,

Universität Basel, Switzerland

Reviewed by:

Offer Erez,

Soroka Medical Center, Israel

Lenka Vokalova,

University Hospital of Basel,

Switzerland

*Correspondence:

Julia Szekeres-Bartho

Szekeres.julia@pte.hu

Specialty section:

This article was submitted to Immunological Tolerance and Regulation,

a section of the journal

Frontiers in Immunology

Received: 09 August 2018 Accepted: 26 November 2018 Published: 13 December 2018

Citation:

Szekeres-Bartho J, Šućurović S and Mulac-Jeričević B (2018) The Role of

Extracellular Vesicles and PIBF in

Embryo-Maternal

Immune-Interactions.

Front. Immunol. 9:2890.

doi: 10.3389/fimmu.2018.02890

\section{The Role of Extracellular Vesicles and PIBF in Embryo-Maternal Immune-Interactions}

\author{
Julia Szekeres-Bartho ${ }^{1,2,3,4 *}$, Sandra Šućurović ${ }^{5}$ and Biserka Mulac-Jeričević ${ }^{5}$ \\ ${ }^{1}$ Department of Medical Biology and Central Electron Microscope Laboratory, Medical School, Pécs University, Pécs, \\ Hungary, ${ }^{2}$ János Szentágothai Research Centre, Pécs University, Pécs, Hungary, ${ }^{3}$ Endocrine Studies, Centre of Excellence, \\ Pécs University, Pécs, Hungary, ${ }^{4}$ MTA-PTE Human Reproduction Research Group, Pécs, Hungary, ${ }^{5}$ Department of \\ Physiology and Immunology, Faculty of Medicine, University of Rijeka, Rijeka, Croatia
}

Pregnancy represents a unique immunological situation. Though paternal antigens expressed by the conceptus are recognized by the immune system of the mother, the immune response does not harm the fetus. Progesterone and a progesterone induced protein; PIBF are important players in re-adjusting the functioning of the maternal immune system during pregnancy. PIBF expressed by peripheral pregnancy lymphocytes, and other cell types, participates in the feto-maternal communication, partly, by mediating the immunological actions of progesterone. Several splice variants of PIBF were identified with different physiological activity. The full length $90 \mathrm{kD}$ PIBF protein plays a role in cell cycle regulation, while shorter splice variants are secreted and act as cytokines. Aberrant production of PIBF isoforms lead to the loss of immune-regulatory functions, resulting in and pregnancy failure. By up regulating Th2 type cytokine production and by down-regulating NK activity, PIBF contributes to the altered attitude of the maternal immune system. Normal pregnancy is characterized by a Th2-dominant cytokine balance, which is partly due to the action of the smaller PIBF isoforms. These bind to a novel form of the IL-4 receptor, and induce increased production of IL-3, IL-4, and $\mathrm{IL}-10$. The communication between the conceptus and the mother is established via extracellular vesicles (EVs). Pre-implantation embryos produce EVs both in vitro, and in vivo. PIBF transported by the EVs from the embryo to maternal lymphocytes induces increased IL-10 production by the latter, this way contributing to the Th2 dominant immune responses described during pregnancy.

Keywords: pregnancy, progesterone, PIBF, NK cells, cytokines, extracellular vesicles

\section{INTRODUCTION}

Fifty per cent of the antigens expressed by the fetus originate from the father. Therefore, they are recognized as foreign and should be "rejected," yet in spite of all odds, the maternal immune system does not attack the fetus.

The immune system of the mother must comply with two conflicting requirements, i.e., while creating a favorable environment for the developing fetus, it has to be prepared to control possible emerging infections. By establishing a delicate balance, the foeto-maternal unit is able to satisfy the interests of both the mother and the fetus. Progesterone, and its mediator the progesterone-induced blocking factor (PIBF) are important players in this process. In addition to its endocrine effects, 
progesterone also acts as an "immunosteroid" (1). Progesterone induces Th2 differentiation of established T cell clones (2) and regulates the homing and activity of uterine NK cells (3), among others, by upregulating HLA-G gene expression (4), which is the ligand for both NK inhibitory and activating receptors. Many of the immunological effects of progesterone are mediated by PIBF.

This review aims to give an overview on the diverse roles of progesterone and PIBF in re-setting the functions of the maternal immune system, and on extracellular vesicles (EVs) as means of establishing the communication between the two sides of the feto-maternal unit.

\section{PROGESTERONE RECEPTORS}

The biological activity of progesterone is mediated by genomic and non-genomic pathways. The former depends on two nuclear progesterone receptor $(\mathrm{PR})$ isoforms, $\mathrm{PRA}$, and $\mathrm{PRB}(5,6)$. Both isoforms are the products of the same gene, but their transcription is controlled by two distinct promoters (7).

Mice lacking PRA are infertile $(8,9)$, while the PRB isoform mediates the effects of progesterone on mammary gland development (10). The reproductive tissue responses to progesterone depend on the relative expression of the two isoforms (11). Progesterone can also signal through membranebound PRs or via the MAPK or PI3K/Akt pathway. The latter entirely bypasses the classical PR pathway, signaling either through the JNK pathway or by increasing cAMP (12).

Studies on PR knock out mice revealed, that PRs are required not only for endometrial receptivity and decidualization (13), but also for establishing an appropriate immune environment in the endometrium (14) (Figure 1). Several studies using nuclear and cytosol binding assays and immunohistochemistry-indicate, that in certain conditions lymphoid cells might express PRs (15-20).

Peripheral lymphocytes of pregnant women, but not those of non-pregnant individuals express PRs $(21,22)$. Earlier we demonstrated an inverse relationship between progesterone binding capacity and cytotoxic activity of peripheral human lymphocytes (23). The cytotoxic activity of pregnancy

\section{PROGESTERONE IN EARLY PREGNANCY}

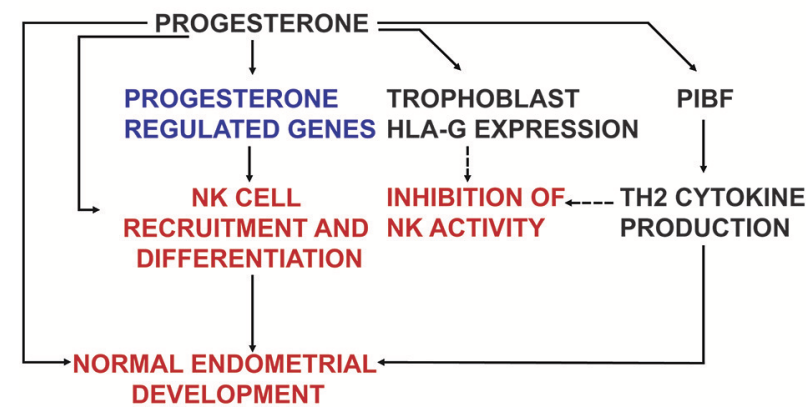

FIGURE 1 | The effects of progesterone on endometrial development and on the immune system in early pregnancy. lymphocytes was significantly reduced by progesterone at concentrations comparable to those, present in pregnancy serum, while 100-fold higher progesterone concentrations were required to alter the cytotoxic activity of lymphocytes from non-pregnant individuals (24). These findings already suggested that pregnancy lymphocytes might contain progesterone binding sites, which enable them to respond to progesterone.

The number of PR positive cells increases throughout normal gestation. In women with recurrent miscarriage, or in those, showing clinical symptoms of threatened pre-term delivery, the $\%$ of PR expressing cells among peripheral lymphocytes, is significantly lower than in women with uneventful pregnancies $(21,22)$. These findings suggest, that the presence of PR positive lymphocytes is required for a normally progressing pregnancy.

PR expression in peripheral lymphocytes or lymphoid cell lines has been confirmed by several studies $(15-17,25,26)$. Both classical PR isoforms are present in peripheral blood NK cells (18), however, PR expression in decidual NK cells is controversial. Van den Heuvel et al. (3) demonstrated PRs in murine decidual NK cells, while Henderson et al. (27) failed to detect of PRs in purified decidual NK cells. Nevertheless, the majority of decidual NK cells are PIBF positive (28).

Both in vitro and in vivo activation of human non-pregnancy lymphocytes result in increased PR expression $(29,30)$. Paternal leukocyte immunization of women with recurrent miscarriage also increases the number of PR expressing lymphocytes (31).

These data indicate that PR expression is a characteristic feature of activated immune cells (Figure 2).

\section{ANTIGEN RECOGNITION}

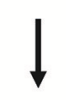

ACTIVATION
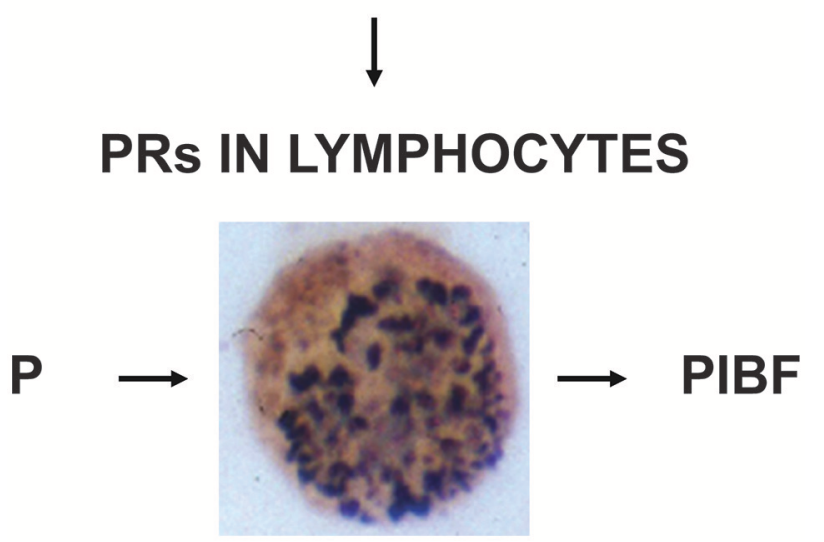

FIGURE 2 | The induction and biological significance of lymphocyte progesterone receptors. Following recognition of fetal antigens, maternal lymphocytes become activated and express progesterone receptors (PR). The presence of PRs enables the cells, to respond to progesterone (P), e.g., by PIBF production. 


\section{PROGESTERONE-REGULATED GENES}

Among the progesterone-regulated genes, the transcription factors Hox-A10, Hox-A11, and the glican binding protein galectin-1 (Gal-1) are the most relevant for the feto- maternal immunological interaction (32). Hox-A10 deficient mice are characterized by a polyclonal $\mathrm{T}$ cell proliferation (33), and impaired decidual NK cell differentiation $(24,25,34,35)$.

Gal-1 expression in the female reproductive system was described in the nineties, and recently, many functional aspects of this lectin during pregnancy have been discovered (36-38). Gal-1 gene expression in the mouse uterine tissues has been shown to be regulated by ovarian steroids during implantation (39). In line with this, Than et al. (40) identified an estrogen response element in the Gal-1 gene.

Altered Gal-1 expression in the placenta has been implicated in several pregnancy pathologies.

Proteomic studies showed that Gal-1 expression is reduced in placental villous tissues from patients with spontaneous miscarriages (41). On the other hand, placental Gal-1 expression was found to be increased in severe preeclampsia (42) as well as in chorioamnionitis (43), possibly representing a fetal response to an exaggerated systemic maternal inflammation.

In pregnant mice, stress-induced Gal-1-deficiency results in an increased rate of fetal loss, which is corrected by progesterone exposure. Gal-1 treatment on the other hand, prevents the stressinduced decrease of progesterone as well as PIBF levels, and restores the resorption rates to a normal level (44). These data suggest a cross-regulation between progesterone and Gal-1 at the foeto-maternal interface.

PIBF is another progesterone-regulated gene. The mouse PIBF1 gene, is transcribed to 16 different mRNAs, the longest of which is 3,677 bp long and includes 18 exons. The predicted protein is a $90 \mathrm{kDa}$ molecule, composed of 756 amino acids (45). The full-length PIBF protein shows a peri-nuclear localization, (46) and has been identified as a component of the pericentriolar satellite (47), suggesting its role in cell cycle regulation. Alternative splicing produces several smaller isoforms, which are localized in the cytoplasm (45) and are accountable for the immunological effects of PIBF.

In murine pregnancy, embryo resorption as well as term delivery are associated with the absence or lower expression of the $\mathrm{N}$ terminal PIBF exons, which might have important functional consequences (48).

The loss of the N-terminal exons results in a significantly reduced production of the full length protein, and also prevents the synthesis of the smaller protein isoforms, which act on the cytokine pattern and NK activity (45).

\section{THE IMMUNO-MODULATING EFFECTS OF PIBF AND THE MAINTENANCE OF PREGNANCY}

PIBF was first described as a $34 \mathrm{kDa}$ protein produced by activated pregnancy lymphocytes (30). It has become evident since, that PIBF might be expressed by various reproductive tissues as well as malignant tumors (49-51). A human study illustrated that trophoblast cells in the placenta could express PIBF proteins of 30, 50, and $90 \mathrm{kDa}$ in first trimester (52).

Several human studies suggest an association between PIBF levels and the outcome of pregnancy. In a prospective cohort study attempting to identify early risk factors for miscarriage, PIBF was one of the factors showing a strong association with miscarriage risk (53). In normal human pregnancy, both serum-and urinary PIBF concentrations increase during gestation, while in women, with miscarriage, or preterm labor, urinary PIBF levels fail to increase (54). Preterm birth was predictable by lower than normal pregnancy PIBF values mesaured at 24-28gestational week (55), but not at 11-13 weeks of gestation (56), suggesting, that predictive value of PIBF determination depends on the interval, between sampling and the onset of labor. In line with this, progestogen-treatment of women with threatened miscarriage corrected the initially low PIBF levels, and in parallel, reduced the miscarriage rate to a similar level of healthy controls (57).

While the full length PIBF has been shown to regulate trophoblast and tumor cell invasiveness (58-60), the smaller isoforms are secreted, bind to the PIBF receptor $(39,61)$ and via their cytokine-like functions, play a role in the materno-fetal relationship, both in animal models and in humans.

Some of the immunological effects of progesterone, e.g., that on NK activity and cytokine balance, are mediated by PIBF.

Earlier studies showed that in mice PIBF protects pregnancy by controlling NK activity (62). Anti-PIBF treatment of pregnant mice results in increased resorption, which are corrected by simultaneously neutralizing NK activity with anti-NK antibodies (62).

Decidual NK cells, are functionally different from their circulating counterparts. Though decidual NK cells selectively overexpress perforin and granzymes A and B $(41,63)$, their cytotoxic activity is low. In normal pregnancy decidual NK cells contribute to creating a favorable environment for placentation, implantation and embryo development (64), yet they are equipped with cytotoxic molecules, to fight intrauterine infections $(65,66)$.

In the day 12 mouse decidua, there is an abundance of PIBF positive granulated cells. These cells are missing from the deciduae of alymphoid mice, but when alymphoid mice are reconstituted of with bone marrow from male $\mathrm{BALB} / \mathrm{c}$ mice, the PIBF positive granulated cells re-appear in the decidua. These data suggest that the PIBF+ cells belong to the lymphoid lineage, and based on their DBA lectin reactivity, to the group of NK cells.

PIBF+ NK cells contain perforin, which co-localizes with PIBF in the cytoplasmic granules. In day 12.5 normal mouse pregnancy only $54 \%$ of the PIBF + decidual NK cells contain perforin, whereas in PIBF deficient mice of the same gestational age, not only do most of the PIBF + NK cells disappear, but all of the remaining ones are perforin positive (28).

This implies that in mice PIBF exerts a pregnancy protective effect by keeping NK activity under restraint. 
The local mechanism of the protective action of PIBF is less easily studied in humans, than in animal models. Nevertheless, a recent study showed that the otherwise scarcely studied decidual $B$ cells produce PIBF under the effect of IL-33, and that these PIBF $+\mathrm{B}$ cells are missing from the choriodecidual area of women with pre-term labor (67) (Nature).

In spite of their high perforin content, spontaneous cytotoxic activity of human decidual NK cells is moderate (68). Progesterone inhibits human NK cytolytic activity in vitro (19), and upregulates HLA-G gene expression (4). Because HLA-G is a ligand for NK inhibitory and activating receptors, upregulation of HLA-G by progesterone might be one of the pathways accounting for the low cytotoxic activity of decidual NK cells.

Decidual NK activity appears to be affected by PIBF. PIBF inhibits upregulation of perforin expression in activated human decidual NK cells and prevents degranulation $(69,70)$.

Though there is no evidence that NK cells directly attack the trophoblast, recurrent miscarriage is often accompanied by increased decidual NK activity (71-75), suggesting that this mechanism might be a factor in the underlying pathology of repeated pregnancy loss.

It is well-established, that while normally progressing pregnancies are characterized by a Th2 dominant cytokine pattern, an excess of Th1-associated cytokines leads to pregnancy termination $(76,77)$. In humans, recurrent miscarriages are associated with a Thl-dominant peripheral cytokine profile (7882).

Both progesterone and PIBF play a role in the induction of the Th2 biased cytokine balance. In the presence of progesterone resting human peripheral blood $\mathrm{T}$ cells differentiate into Th2-like clones, furthermore, progesterone treatment of Th1-like $\mathrm{T}$ cell clones shifts the cytokine production of these cells toward Th2 (2). Neutralization of endogenous PIBF activity in pregnant mice by specific anti-PIBF antibody terminates pregnancy, reduces the synthesis of IL-10, and increases that of IFN- $\gamma$ (83).

The PIBF receptor is a glycosylphosphatidylinositol (GPI)anchored protein, which, for signaling, temporarily associates with the alpha chain of the IL-4 receptor $(39,61)$. Engagement of the PIBF receptor results in immediate STAT6 activation, whereas, a $24 \mathrm{~h}$ incubation with progesterone is needed to phosphorylate STAT6, indicating, that the effect of progesterone on Th2 cytokine production is mediated by PIBF (61) (Figure 3).

By signaling via this novel form of the $\operatorname{IL}-4$ receptor $(39,61)$, PIBF induces increased production of IL-3, IL-4, and IL-10 by activated murine lymphocytes (84).

Raghupathy et al. $(78,79)$ investigated the production of Th1 and Th2 cytokines by progesterone treated peripheral blood lymphocytes isolated from women with recurrent miscarriage. They showed that progestogen induced PIBF production downregulates the production of Thl-type cytokines and stimulates the production of Th2-type cytokines. Furthermore, progestogen treatment of women with pre-term delivery induces a Th2 dominant cytokine pattern $(78,79)$.

Taken together, these data suggest, that by up regulating Th2 type cytokine production and by down-regulating NK activity PIBF affects the immune response in a way, which might have an impact on the foeto-maternal relationship.

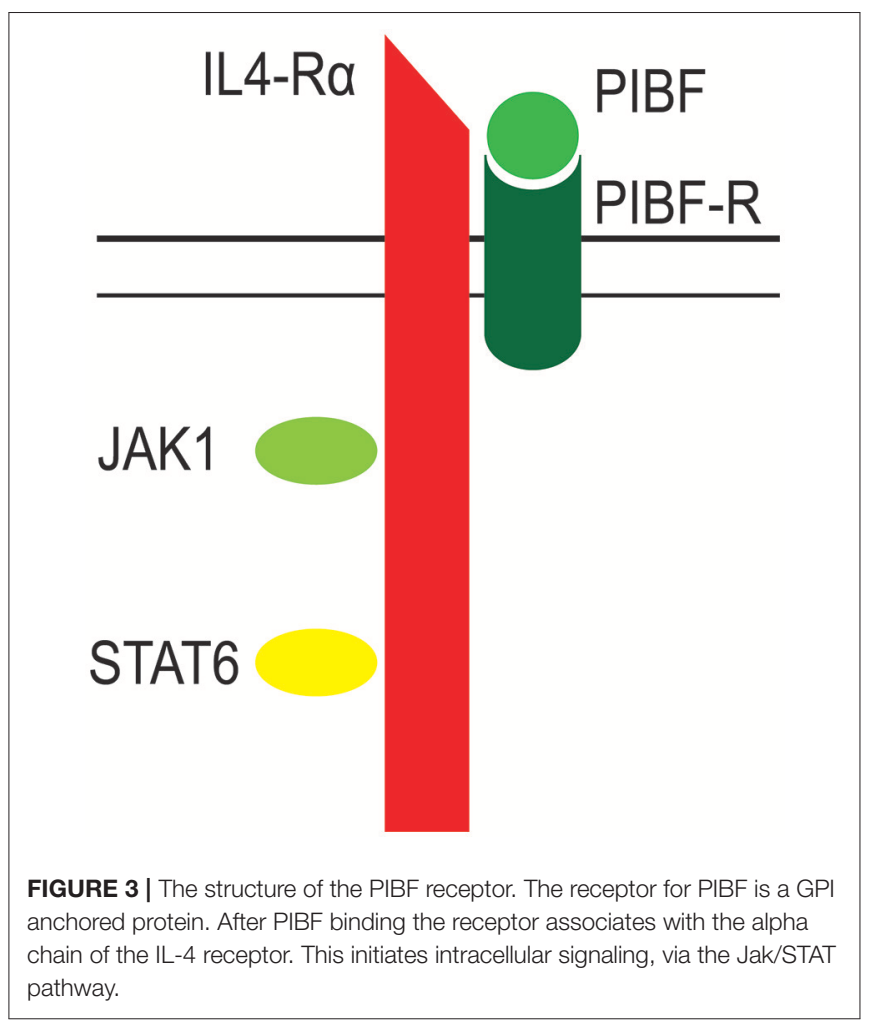

\section{THE PERI-IMPLANTATION EMBRYO COMMUNICATES WITH THE MATERNAL IMMUNE SYSTEM VIA EXTRACELLULAR VESICLES}

Earlier studies described a communication between the embryo and the maternal immune system. Embryo culture media were shown to exert an immunosuppressive activity (84). In line with this, incubation of human peripheral lymphocytes with the culture media of fertilized eggs, but not with follicular fluid resulted in increased IL-10 mRNA expression by the lymphocytes (85).

These data suggest that embryo derived signals, can influence the maternal immune response, however, the mechanism of signal transport has not been thoroughly investigated.

In recent years EVs have received much attention. These membrane-coated structures may express phosphatidylserine (PS) in their membrane (86), which reacts with Annexin V. EVs are categorized by their origin and size (87). Exosomes are $30-100 \mathrm{~nm}$, and originate from internalized endocytic vesicles. Microvesicles $\left(100 \mathrm{~nm}^{-1} \mu \mathrm{m}\right.$ in diameter), are shed from the plasma membrane by budding, and apoptotic vesicles $(1-5 \mu \mathrm{m}$ in diameter) are released from cells undergoing apoptosis (88).

All types of cells produce EVs which transport various cargos, (including proteins, nucleic acids, and lipids) from one cell to the other. Proteins, e.g., cytokines carried and released by EVs could initiate signaling pathways, and thus alter the biological functions of the target cells $(89,90)$. 
EVs might be considered as candidates for conveying the information from the embryo to the mother. The message carried by EVs has been shown to affect the reproductive process at different points.

EVs have been demonstrated in mouse oocytes (91) as well as in the follicular fluid (92-96) and extra villous trophoblast (97). The tetraspanins CD9 and CD81 expressed by oocyte derived EVs have been suggested to play a role in sperm-oocyte membrane fusion (98-100). Follicular fluid exosomes contain miRNAs, some of them targeting genes that regulate oocyte growth (95) as well as different pathways of reproduction, and endocrine functions (94).

EV-mediated interactions between the endometrium and the blastocyst promote implantation (101). In sheep endometrium, $\mathrm{EV}$ production is controlled by progesterone, and endometrium derived EVs were shown to reach the embryo, (102).

EVs from a human uterine epithelial cells express the extracellular matrix metalloprotease inducer (103) which induces the expression of MMPs, thus EVs might also play a role in endometrial remodeling $(101,103,104)$.

EVs can be produced by virtually all cell types, however it has been debated, whether a single embryo would be able to produce a detectable amount of EVs. The more so, because the culture medium contains serum or serum albumin, both of which could also be a source of EVs. In a review Tannetta et al. (105) points out the difficulty of measuring EVs in embryo culture medium.

Now there is evidence, that pre-implantation embryos produce EVs both in vitro and in vivo (106).

Earlier we showed that spent media of in vitro cultured human embryos contain a significantly higher number of EVs, than empty media, and the number of nucleic acid containing EVs in day 5 human embryo culture media, might serve as an indicator of embryo competence (106). Other groups have also reported the presence of EVs in embryo culture medium. It is now obvious that embryos release EVs, which are taken up by close by cells (90). Giacomini et al. (107) characterized HLA-G containing EVs isolated from conditioned media from in vitro cultured human embryos. EVs were demonstrated in the culture medium of bovine blastocyst and the characteristics of these EVs varied depending on embryo competence (108). Qu et al. (109) showed that the negative effects of culture media replacement during embryo culture are due to the loss of embryo derived EVs, and can be corrected by exosome supplementation. This suggests, that embryo derived EVs do indeed carry molecules that promote normal embryo development.

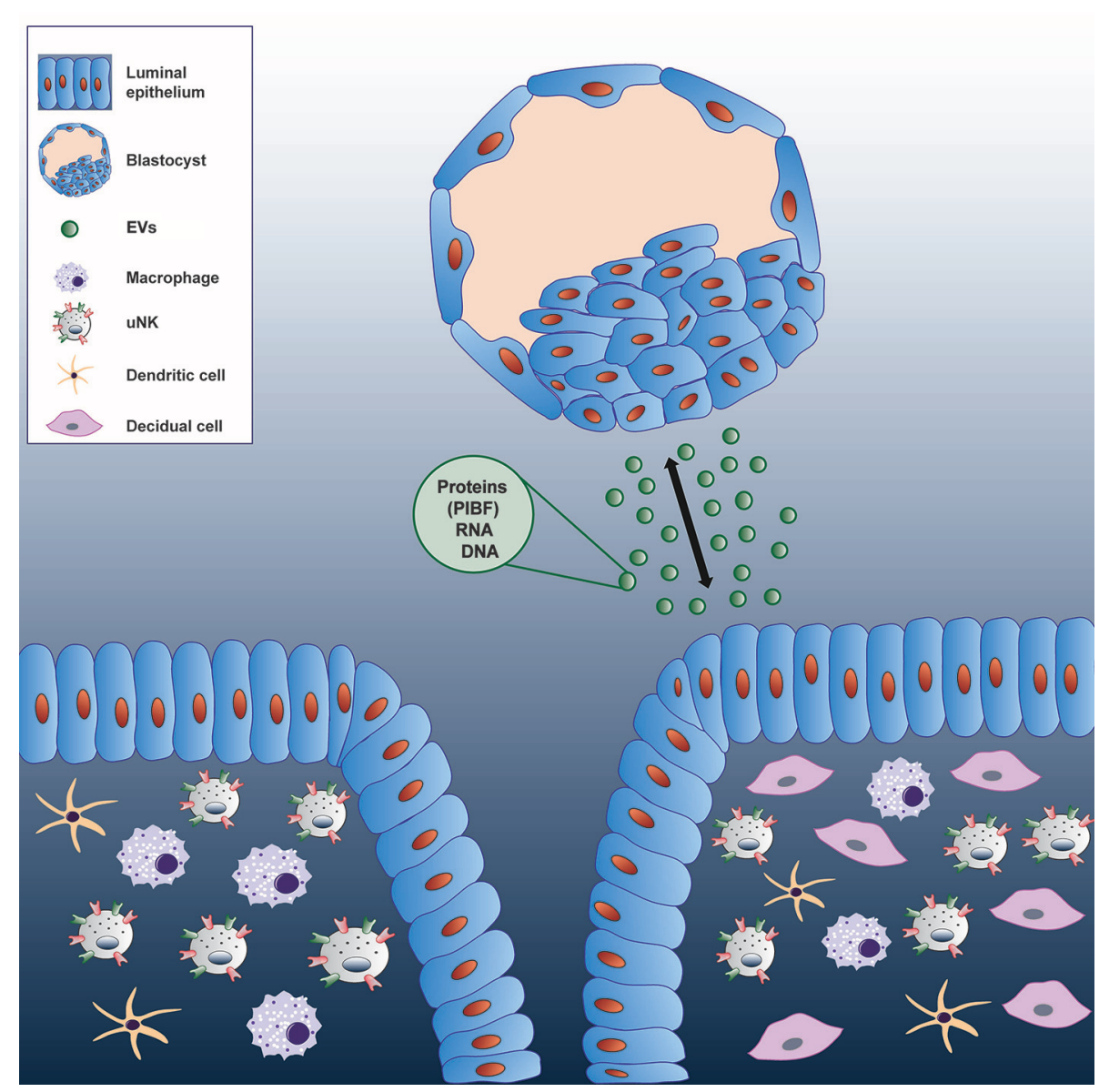

FIGURE 4 | Communication between the embryo and the maternal immune system via extracellular vesicles. 
Embryo-derived EVs might also communicate with the maternal immune system by presenting antigens $(110,111)$, carrying MHC molecules (112-115), or cytokines (116-121). HLA-G-positive EVs isolated from the plasma from healthy term pregnant women have been reported to bind to T lymphocytes (122), and moderately decrease peripheral T lymphocyte STAT3 phosphorylation (122). EVs at the same time can induce proinflammatory cytokines and chemokines in primary macrophage cultures $(123,124)$.

EVs bind to CD8+ and-though to a lesser degree to CD4+ lymphocytes-, via the phosphatidylserine-phosphatidylserine receptor interaction (125). CD4+ and CD8+ cells express similar numbers of phosphatidylserine receptors, therefore, it is likely, that in addition to the phosphatidylserine-phosphatidylserine receptor interaction, other, yet unidentified mechanisms might also be involved in binding of EVs to CD8+ cells. With immunoelectron microscopy we identified PIBF in embryo-derived EVs, and showed that these PIBF containing EVs might affect the immune response (125).

Incubation of murine spleen cells with embryo-derived EVs, increased the number of IL-10+ cells among peripheral CD8+ cells, but not in the CD4+ population. IL-10 producing CD8+ $\mathrm{T}$ lymphocytes might moderate antigen-induced inflammatory responses, since these cells have been shown to control influenza virus induced inflammation in the foet (126), and to prevent liver damage during chronic hepatitis $\mathrm{C}$ virus infection (127).

\section{REFERENCES}

1. Siiteri PK, Febres F, Clemens LE, Chang RJ, Gondos B, Stites DP. Progesterone and the maintenance of pregnancy: is progesterone nature's immunosuppressant? Ann NY Acad Sci. (1997) 286:384-97. doi: 10.1111/j.1749-6632.1977.tb29431.x

2. Piccinni MP, Giudizi MG, Biagiotti R, Beloni L, Giannarini L, Sampognaro $\mathrm{S}$, et al. Progesterone favors the development of human $\mathrm{T}$ helper cells producing Th2-type cytokines and promotes both IL-4 production and membrane CD30 expression in established Th1 cells clones. J Immunol. (1995) 155:128-33.

3. Van den Heuvel MJ, Chantakru S, Xumei X, Evans EE, Tekpetey F, Mote $\mathrm{PA}$, et al. Trafficking of circulating pro-NK cells to the decidualizing uterus: regulatory mechanisms in the mouse and human. Immunol Invest. (2005). 34:273-93. doi: 10.1081/IMM-200064488

4. Yie SM, Xiao R, Librach CL. Progesterone regulates HLA-G gene expression through a novel progesterone response element Hum Reprod. (2006) 21:2538-44. doi: 10.1093/humrep/del126

5. Li X, Lonard DM, O'Malley BW. A contemporary understanding of progesterone receptor function. Mech Ageing Dev. (2004) 125:669-78. doi: 10.1016/j.mad.2004.04.007

6. Mulac-Jericevic B, Conneely OM. Reproductive tissue selective actions of progesterone receptors. Reproduction (2004) 128:139-46. doi: 10.1530/rep.1.00189

7. Li X, O'Malley BW. Unfolding the action of progesterone receptor. J Biol Chem. (2003) 278:39261-4. doi: 10.1074/jbc.R300024200

8. Mulac-Jericevic B, Mullinax RA, DeMayo FJ, Lydon JP, Conneely OM. Subgroup of reproductive functions of progesterone mediated by progesterone receptor-B isoform. Science (2000) 289:1751-4. doi: 10.1126/science.289.5485.1751

9. Mulac-Jericevic B, Lydon JP, DeMayo FJ, Conneely OM. Defective mammary gland morphogenesis in mice lacking the progesterone receptor $\mathrm{B}$ isoform.
Pre-treatment of EVs with an anti-PIBF antibody abrogates the above described effect of the EVs. These data suggest that PIBF transported by the EVs from the embryo to maternal lymphocytes might induce increased IL-10 production by the latter, this way contributing to the Th2 dominant immune responses described during pregnancy. The finding is in line with our earlier data, (83) showing increased IL-10 production of murine spleen cells in the presence of PIBF.

This pathway might have its significance in reproduction. Because embryo derived EVs transport various molecules, - PIBF, among others-, it cannot be ruled out, that these structures act as means of feto-maternal or materno-fetal communication in the peri-implantation period (Figure 4).

\section{AUTHOR CONTRIBUTIONS}

JS-B wrote the paper. BM-J, SŠ, and JS-B designed and performed the experiments.

\section{ACKNOWLEDGMENTS}

This work was supported by GINOP-2.3.2-15-201600021, PTE ÁOK-KA 2017-22 EFOP-3.6.1.-16-2016-00004, EFOP-3.6.3VEKOP-16-2017-00009 to JS-B, and Croatian science foundation (HRZZ 3432) BM-J and a grant from the University of Rijeka, Croatia 13.06.1.1.08 BM-J.

Proc Natl Acad Sci USA. (2003) 100:9744-9. doi: 10.1073/pnas.17327 07100

10. Conneely OM, Jericevic BM, Lydon JP. Progesterone receptors in mammary gland development and tumorigenesis. J Mammary Gland Biol Neoplasia. (2003) 8:205-14. doi: 10.1023/A:1025952924864

11. Fernandez-Valdivia R, Mukherjee A, Mulac-Jericevic B, Conneely OM, DeMayo FJ, Amato P, et al. Revealing progesterone's role in uterine and mammary gland biology: insights from the mouse. Semin Reprod Med. (2005) 23:22-37. doi: 10.1055/s-2005-864031

12. Gellersen B, Fernandes MS, Brosens JJ. Non-genomic progesterone actions in female reproduction. Hum Reprod Update (2009) 15:119-38. doi: 10.1093/humupd/dmn044

13. Lydon JP, DeMayo FJ, Funk CR, Mani SK, Hughes AR, Montgomery CA, et al. Mice lacking progesterone receptor exhibit pleiotropic reproductive abnormalities. Genes Dev. (1995) 9:2266-78. doi: 10.1101/gad.9.18. 2266

14. Tibbetts TA, Conneely OM, O'Malley BW. Progesterone via its receptor antagonizes the pro-inflammatory activity of estrogen in the mouse uterus. Biol Reprod. (1999) 60:1158-65. doi: 10.1095/biolreprod60.5.1158

15. Kimoto Y. A single human cell expresses all messenger ribonucleic acids: the arrow of time in a cell. Mol Gen Genet. (1998) 258:233-9. doi: $10.1007 /$ s004380050727

16. Daniel L, Vincent C, Rousset F, Klein B, Bataille R, Flacher M, et al. Estrogen and progesterone receptors in some human myeloma cell lines and murine hybridomas. J Steroid Biochem. (1988) 30:363-7. doi: 10.1016/0022-4731(88)90124-0

17. Pasanen S, Ylikomi T, Palojoki E, Syvala H, Pelto-Huikko M, Tuohimaa P. Progesterone receptor in chicken bursa of Fabricius and thymus: evidence for expression in B-lymphocytes. Mol Cell Endocrinol. (1998) 141:119-28. doi: 10.1016/S0303-7207(98)00086-0

18. Arruvito L, Giulianelli S, Flores AC, Paladino N, Barboza M, Lanari $\mathrm{C}$, et al. NK cells expressing a progesterone receptor are susceptible 
to progesterone-induced apoptosis. J Immunol. (2008) 180:5746-53. doi: 10.4049/jimmunol.180.8.5746

19. Hansen KA, Opsahl MS, Nieman LK, Baker JR Jr, Klein TA. Natural killer cell activity from pregnant subjects is modulated by RU 486. Am J Obstetr Gynecol. (1992) 166:87-90. doi: 10.1016/0002-9378(92)91835-X

20. Roussev RG, Higgins NG, McIntyre JA. Phenotypic characterization of normal human placental mononuclear cells. J Reprod Immunol. (1993) 25:15-29. doi: 10.1016/0165-0378(93)90039-K

21. Szekeres-Bartho J, Szekeres GY, Debre P, Autran B, Chaouat G. Reactivity of lymphocytes to a progesterone receptor-specific monoclonal antibody. Cell Immunol. (1990) 125:273-83. doi: 10.1016/0008-8749(90)90083-4

22. Szekeres-Bartho J, Reznikoff-Etievant MF, Varga P, Varga Z, Chaouat G. Lymphocytic progesterone receptors in human pregnancy. I Reprod Immunol. (1989) 16:239-47. doi: 10.1016/0165-0378(89)90053-3

23. Szekeres-Bartho J, Csernus V, Hadnagy J, Pacsa AS. Immunosuppressive effect of serum progesterone during pregnancy depends on the progesterone binding capacity of the lymphocytes. J Reprod Immunol. (1983) 5:81-8. doi: 10.1016/0165-0378(83)90003-7

24. Szekeres-Bartho J, Hadnagy J, Pacsa AS. The suppressive effect of progesterone on lymphocyte cytotoxicity: unique progesterone sensitivity of pregnancy lymphocytes. J Reprod Immunol. (1985) 7:121-8. doi: 10.1016/0165-0378(85)90066-X

25. Szekeres-Bartho J, Barakonyi A, Polgar B, Par G, Faust Z, Palkovics T, et al. The role of $\mathrm{g} / \mathrm{d} \mathrm{T}$ cells in progesterone-mediated immunomodulation during pregnancy: a review. Am J Reprod Immunol. (1999) 42:44-8. doi: 10.1111/j.1600-0897.1999.tb00464.x

26. Barakonyi A, Kovacs KT, Miko E, Szereday L, Varga P, SzekeresBartho J, et al. Recognition of nonclassical HLA class I antigens by gamma delta T cells during pregnancy. J Immunol. (2002) 168:2683-8. doi: 10.4049/jimmunol.168.6.2683

27. Henderson TA, Saunders PT, Moffet-King A, Grrome NO, Critchley HO. Steroid receptor expression in uterine natural killer cells. J Clin Endocrinol Metabol. (2003) 88:440-9. doi: 10.1210/jc.2002-021174

28. Bogdan A, Berta G, Szekeres-Bartho J. PIBF positive uterine NK cells in the mouse decidua. J Reprod Immunol. (2017) 119:38-43. doi: 10.1016/j.jri.2016.12.001

29. Paldi A, d'Auriol L, Misrahi M, Bakos AM, Chaouat G, Szekeres-Bartho J. Expression of the gene coding for the progesterone receptor in activated human lymphocytes. Endocrine J. (1994) 2:317-321.

30. Szekeres-Bartho J, Weill BJ, Mike G, Houssin D, Chaouat G. Progesterone receptors in lymphocytes of liver-transplanted and transfused patients. Immunol Lett. (1989) 22:259-61. doi: 10.1016/0165-2478(89)90162-4

31. Chiu L, Nishimura M, Ishi Y, Nieda M, Maeshima M, Takedani Y, et al. Enhancement of the expression of progesterone receptor on progesterone -treated lymphocytes after immunotherapy in unexplained recurrent spontaneous abortion. Am J Reprod Immunol. (1996) 35:552-7. doi: 10.1111/j.1600-0897.1996.tb00056.x

32. Choe YS, Shim C, Choi D, Lee CS, Lee KK, Kim K. Expression of galectin-1 mRNA in the mouse uterus is under the control of ovarian steroids during blastocyst implantation. Mol Reprod Dev. (1997) 48:261-66.

33. Yao MW, Lim H, Schust DJ, Choe SE, Farago A, Ding Y, et al. Gene expression profiling reveals progesterone-mediated cell cycle and immunoregulatory roles of Hoxa-10 in the preimplantation uterus. Mol Endocrinol. (2003) 17:610-27. doi: 10.1210/me.2002-0290

34. Rahman MA, Li M, Li P, Wang H, Dey SK, Das SK. Hoxa-10 deficiency alters region-specific gene expression and perturbs differentiation of natural killer cells during decidualization. Dev Biol. (2006) 290:105-17. doi: 10.1016/j.ydbio.2005.11.016

35. Daftary GS, Taylor HS. Endocrine regulation of HOX genes. Endocrine Rev. (2006) 27:331-55. doi: 10.1210/er.2005-0018

36. Phillips B, Knisley K, Weitlauf KD, Dorsett J, Lee V, Weitlauf $H$. Differential expression of two beta-galactoside-binding lectins in the reproductive tracts of pregnant mice. Biol Reprod. (1996) 55:548-58. doi: 10.1095/biolreprod55.3.548

37. Maquoi E, van den Brûle FA, Castronovo V, Foidart JM. Changes in the distribution pattern of galectin- 1 and galectin- 3 in human placenta correlates with the differentiation pathways of trophoblasts. Placenta (1997) 18:433-9.

38. Barrientos G, Freitag N, Tirado-González I, Unverdorben L, Jeschke $\mathrm{U}$, Thijssen VL, et al. Involvement of galectin-1 in reproduction: past, present and future. Hum Reprod Update. (2014) 20:175-93. doi: 10.1093/humupd/dmt040

39. Choe YS, Shim C, Choi D, Lee CS, Lee KK, Kim K. Expression of galectin-1 mRNA in the mouse uterus is under the control of ovarian steroids during blastocyst implantation. Mol Reprod Dev. (1997) 48:261-6.

40. Than NG, Romero R, Erez O, Weckle A, Tarca AL, Hotra J, et al. Emergence of hormonal and redox regulation of galectin-1 in placental mammals: implication in maternal-fetal immune tolerance. Proc Natl Acad Sci USA. (2008) 14:105. doi: 10.1073/pnas.0807606105

41. Liu AX, Jin F, Zhang WW, Zhou TH, Zhou CY, Yao WM, et al. Proteomic analysis on the alteration of protein expression in the placental villous tissue of early pregnancy loss. Biol Reprod. (2006) 75:414-20. doi: 10.1095/biolreprod.105.049379

42. Than NG, Erez O, Wildman DE, Tarca AL, Edwin SS, Abbas A, et al. Severe preeclampsia is characterized by increased placental expression of galectin-1. J Matern Fetal Neonatal Med. (2008) 21:429-42. doi: 10.1080/14767050802041961

43. Than NG, Kim SS, Abbas A, Han YM, Hotra J, Tarca AL, et al. Chorioamnionitis and increased galectin-1 expression in PPROM -an antiinflammatory response in the fetal membranes? Am J Reprod Immunol. (2008) 60:298-311. doi: 10.1111/j.1600-0897.2008.00624.x

44. Blois S, Ilarregui JM, Tometten M, Garcia M, Orsal AF, Toscano M, et al. A pivotal role for galectin-1 in fetal tolerance. Nat Med. (2007) 13:1450-7. doi: $10.1038 / \mathrm{nm} 1680$

45. Polgar B, Kispal G, Lachmann M, Paar C, Nagy E, Csere P, et al. Molecular cloning and immunologic characterization of a novel cDNA coding for progesterone-induced blocking factor. J Immunol. (2003) 171:5956-63. doi: $10.4049 /$ jimmunol.171.11.5956

46. Lachmann M, Gelbmann D, Kálmán E, Polgár B, Buschle M, von Gabain A, et al. PIBF (progesterone induced blocking factor) is overexpressed in highly proliferating cells and associated with the centrosome. Int J of Cancer (2004) 112:51-60. doi: 10.1002/ijc.20326

47. Kim K, Rhee K. The pericentriolar satellite protein CEP90 is crucial for integrity of the mitotic spindle pole. J Cell Sci. (2011) 124:338-47. doi: $10.1242 /$ jcs.078329

48. Bogdan A, Polgar B, Szekeres-Bartho J. Progesterone induced blocking factor isoforms in normal and failed murine pregnancies. Am J Reprod Immunol. (2014) 71:131-6. doi: 10.1111/aji.12183

49. Srivastava MD, Thomas A, Srivastava BI, Check JH. Expression and modulation of progesterone induced blocking factor (PIBF) and innate immune factors in human leukemia cell lines by progesterone and mifepristone. Leuk Lymphoma. (2007) 48:1610-7. doi: 10.1080/10428190701471999

50. Kyurkchiev D, Naydenov E, Tumangelova-Yuzeir K, Ivanova-Todorova E, Belemezova K, Bochev I, et al. Cells isolated from human glioblastoma multiforme express progesterone-induced blocking factor (PIBF). Cell $\mathrm{Mol}$ Neurobiol. (2014) 34:479-89. doi: 10.1007/s10571-014-0031-3

51. Gutiérrez-Rodríguez A, Hansberg-Pastor V, Camacho-Arroyo I. Proliferative and invasive effects of progesterone-induced blocking factor in human glioblastoma cells. Biomed Res Int. (2017) 2017:1295087. doi: 10.1155/2017/1295087

52. Anderle C, Hammer A, Polgar B, Hartmann M, Wintersteiger R, Blaschitz A, et al. Human trophoblast cells express the immunomodulator progesterone-induced blocking factor. J Reprod Immunol. (2008) 79:26-36. doi: 10.1016/j.jri.2008.06.002

53. Nakamura K, Sheps S, Arck PC. Stress and reproductive failure: past notions, present insights and future directions. J Assist Reprod Genet. (2008) 25:47-62. doi: 10.1007/s10815-008-9206-5

54. Polgár B, Nagy E, Mikó E, Varga P, Szekeres-Bartho J. Urinary progesteroneinduced blocking factor concentration is related to pregnancy outcome. Biol Reprod. (2004) 71:1699-705. doi: 10.1095/biolreprod.104.030437

55. Hudić I, Szekeres-Bartho J, Stray-Pedersen B, Fatušić Z, Polgar B, et al. Lower urinary and serum progesterone-induced blocking factor in women with preterm birth. J Reprod Immunol. (2016) 117:66-69. doi: 10.1016/j.jri.2016.07.003

56. Beta J, Szekeres-Bartho J, Skyfta E, Akolekar R, Nicolaides KH. Maternal serum progesterone-induced blocking factor at 11-13 weeks' gestation in spontaneous early preterm delivery. Fetal Diagn Ther. (2011) 29:197-200. doi: $10.1159 / 000322388$ 
57. Kalinka J, Szekeres-Bartho J. The impact of dydrogesterone supplementation on hormonal profile and progesterone-induced blocking factor concentrations in women with threatened abortion. Am J Reprod Immunol. (2005) 53:166-71. doi: 10.1111/j.1600-0897.2005.00261.x

58. Miko E, Halasz M, Jericevic-Mulac B, Wicherek L, Arck P, Arató, G. Progesterone-induced blocking factor (PIBF) and trophoblast invasiveness. J Reprod Immunol. (2011) 90:50-7. doi: 10.1016/j.jri.2011.03.005

59. Halasz M, Polgar B, Berta G, Czimbalek L, Szekeres-Bartho J. Progesteroneinduced blocking factor differentially regulates trophoblast and tumor invasion by altering matrix metalloproteinase activity. Cell Mol Life Sci. (2013) 70:4617-30. doi: 10.1007/s00018-013-1404-3

60. Balassa T, Berta G, Jakab L, Bohonyi N, Szekeres-Bartho J. The effect of the progesterone-induced blocking factor (PIBF) on E-cadherin expression, cell motility and invasion of primary tumour cell lines. J Reprod Immunol. (2018) 125:8-15. doi: 10.1016/j.jri.2017.10.047

61. Kozma N, Halasz M, Polgar B, Poehlmann TG, Markert UR, Palkovics $\mathrm{T}$, et al. Progesterone-induced blocking factor activates STAT6 via binding to a novel IL-4 receptor. J Immunol. (2006) 176:819-26. doi: 10.4049/jimmunol.176.2.819

62. Szekeres-Bartho J, Par G, Dombay GY, Smart YC, Volgyi Z. The antiabortive effect of progesterone-induced blocking factor in mice is manifested by modulating NK activity. Cell Immunol. (1997) 177:194-99. doi: 10.1006/cimm.1997.1090

63. Koopman LA, Kopcow HD, Rybalov B, Boyson JE, Orange JS, Schatz F, et al. Human decidual natural killer cells are a unique NK cell subset with immunomodulatory potential. J Exp Med. (2003) 198:1201-12. doi: 10.1084/jem.20030305

64. Redhead ML, Portilho NA, Felker AM, Mohammad S, Mara DL, Croy BA. The Transcription Factor NFIL3 is essential for normal placental and embryonic development but not for uterine natural killer (UNK) cell differentiation in mice. Biol Reprod. (2016) 94:101. doi: 10.1095/biolreprod.116.138495

65. Quillay H, El Costa H, Duriez M, Marlin R, Cannou C, Madec Y, et al. NK cells control HIV-1 infection of macrophages through soluble factors and cellular contacts in the human decidua. Retrovirology. (2016) 13:39. doi: 10.1186/s12977-016-0271-z

66. Barel MT, Ressing M, Pizzato N, van Leeuwen D, Le Bouteiller P, Lenfant F, et al. Human cytomegalovirus-encoded US2 differentially affects surface expression of MHC class I locus products and targets membrane-bound, but not soluble HLA-G1 for degradation. J Immunol. (2003) 171:6757-65. doi: 10.4049/jimmunol.171.12.6757

67. Huang B, Faucette AN, Pawlitz MD, Pei B, Goyert JW, Zhou JZ, et al. Interleukin-33-induced expression of PIBF1 by decidual B cells protects against preterm labor. Nat Med. (2017) 23:128-35. doi: 10.1038/ nm. 4244

68. Crncic TB, Laskarin G, Frankovic KJ, Tokmadzic VS, Strobo N, Bedenicki I, et al. Early pregnancy decidual lymphocytes beside perforin use Fas ligand (FasL) mediated cytotoxicity. J Reprod Immunol. (2007) 73:108-17. doi: 10.1016/j.jri.2006.07.001

69. Faust Z, Laskarin G, Rukavina D, Szekeres-Bartho J. Progesterone-induced blocking factor inhibits degranulation of natural killer cells. Am J Reprod Immunol. (1999) 42:71-5.

70. Laskarin G, Strbo N, Sotosek V, Rukavina D, Faust Z, SzekeresBartho J, et al. Progesterone directly and indirectly affects perforin expression in cytolytic cells. Am J Reprod Immunol. (1999) 42:312-20. doi: 10.1111/j.1600-0897.1999.tb00107.x

71. Quenby S, Farquharson R. Uterine natural killer cells, implantation failure and recurrent miscarriage. Reprod Biomed Online (2006) 13:24-8. doi: $10.1016 /$ S1472-6483(10)62012-3

72. Veljkovic Vujaklija D, Dominovic M, Gulic T, Mahmutefendic H, Haller H, Saito $S$, et al. Granulysin expression and the interplay of granulysin and perforin at the maternal-fetal interface. J Reprod Immunol. (2013) 97:186-96. doi: 10.1016/j.jri.2012.11.003

73. Yamada H, Kato EH, Kobashi G, Ebina Y, Shimada S, Morikawa M, et al. High NK cell activity in early pregnancy correlates with subsequent abortion with normal chromosomes in women with recurrent abortion. Am J Reprod Immunol. (2001) 46:132-6. doi: 10.1111/j.8755-8920.2001. 460203.x
74. Quenby S, Nik H, Innes B, Lash G, Turner M, Drury J, et al. Uterine natural killer cells and angiogenesis in recurrent reproductive failure. Hum Reprod. (2009) 24:45-54. doi: 10.1093/humrep/den348

75. Lachapelle MH, Miron P, Hemmings R, Roy DC. Endometrial TB, and NK cells in patients with recurrent spontaneous abortion. Altered profile and pregnancy outcome. J Immunol. (1996) 156:4027-34.

76. Wegmann TG, Lin H, Guilbert L, Mosmann TR. Bidirectional cytokine interactions in the maternal-fetal relationship: is successful pregnancy a TH2 phenomenon? Immunol Today (1993) 14:353-6. doi: 10.1016/0167-5699(93)90235-D

77. Raghupathy R. Th1-type immunity is incompatible with successful pregnancy. Immunol Today (1997) 18:478-82.

78. Raghupathy R, Al Mutawa E, Makhseed M, Azizieh F, Szekeres-Bartho $\mathrm{J}$. Modulation of cytokine production by dydrogesterone in lymphocytes from women with recurrent abortion. Brit J Ob Gyn. (2005) 112:1096-01. doi: 10.1111/j.1471-0528.2005.00633.x

79. Raghupathy R, Al-Mutawa E, Al-Azemi M, Makhseed M, Azizieh F, Szekeres-Bartho J. The progesterone-induced blocking factor (PIBF) modulates cytokine production by lymphocytes from women with recurrent miscarriage and with preterm delivery. J Reprod Immunol. (2009) 80:91-9. doi: 10.1016/j.jri.2009.01.004

80. Rezaei A, Dabbagh A. T-helper (1) cytokines increase during early pregnancy in women with a history of recurrent spontaneous abortion. Med Sci Monit. (2002) 8:CR607-10.

81. Hossein H, Mahroo M, Abbas A, Firouzeh A, Nadia H. Cytokine production by peripheral blood mononuclear cells in RM. Cytokine (2004) 28:83-6. doi: $10.1016 /$ j.cyto.2004.07.002

82. Wilson B, Moor J, Jenkins C, Miller H, Walker JJ, McLean MA, et al. Abnormal first trimester serum interleukin 18 levels are associated with a poor outcome in women with a history of RM. Am J Reprod Immunol. (2004) 51:156-9. doi: 10.1046/j.8755-8920.2003.00126.x

83. Szekeres-Bartho J, Faust Z, Varga P, Szereday L, Kelemen K. The immunological pregnancy protective effect of progesterone is manifested via controlling cytokine production. Am J Reprod Immunol. (1996) 35:348-51. doi: 10.1111/j.1600-0897.1996.tb00492.x

84. Szekeres-Bartho J, Wegmann TG. A progesterne-dependent immunomodulatory protein alters the Th1/Th2 balance J. Reprod Immunol. (1996) 31:81-95. doi: 10.1016/0165-0378(96)00964-3

85. Daya S, Clark DA. Immunosuppressive factor (or factors) produced by human embryos in vitro. N Engl. J Med. (1986) 24:1551-2.

86. Kelemen K, Paldi A, Tinneberg H, Torok A, Szekeres-Bartho J. Early recognition of pregnancy by the maternal immune system. Am J Reprod Immunol. (1998) 39:351-5. doi: 10.1111/j.1600-0897.1998.tb00368.x

87. Morel O, Jesel L, Freyssinet J-M, Toti F. Cellular mechanisms underlying the formation of circulating microparticles. Arterioscler Thromb Vasc Biol. (2011) 31:15-26. doi: 10.1161/ATVBAHA.109.200956

88. Raposo G, Stoorvogel W. Extracellular vesicles: exosomes, microvesicles, and friends. J Cell Biol. (2013) 200:373-83. doi: 10.1083/jcb.201211138

89. Desrochers LM, Bordeleau F, Reinhart-King CA, Cerione RA, Antonyak MA. Microvesicles provide a mechanism for intercellular communication by embryonic stem cells during embryo implantation. Nat Commun. (2016) 7:11958. doi: 10.1038/ncomms11958

90. Saadeldin IM, Kim SJ, Choi YB, Lee BC. Improvement of cloned embryos development by co-culturing with parthenotes: a possible role of exosomes/microvesicles for embryos paracrine communication. Cell Reprogr. (2014) 16:223e234. doi: 10.1089/cell.2014.0003

91. Barraud-Lange V, Chalas Boissonnas C, Serres C, Auer J, Schmitt A, Lefevre B, et al. Membrane transfer from oocyte to sperm occurs in two CD9independent ways that do not supply the fertilising ability of Cd9-deleted oocytes. Reproduction (2012) 144:53-66. doi: 10.1530/REP-12-0040

92. da Silveira JC, Veeramachaneni DN, Winger QA, Carnevale EM, Bouma GJ. Cell-secreted vesicles in equine ovarian follicular fluid contain miRNAs and proteins: a possible new form of cell communication within the ovarian follicle. Biol Reprod. (2012) 86:71. doi: 10.1095/biolreprod.111.093252

93. Diez-Fraile A, Lammens T, Tilleman K, Witkowski W, Verhasselt B, de Sutter P, et al. Age-associated differential microRNA levels in human follicular fluid reveal pathways potentially determining fertility and success of in vitro fertilization. Hum Fertil. (2014) 17:90-8. doi: 10.3109/14647273.2014.897006 
94. Sang Q, Yao Z, Wang H, Feng R, Zhao X, Xing Q, et al. Identification of microRNAs in human follicular fluid: characterization of microRNAs that govern steroidogenesis in vitro and are associated with polycystic ovary syndrome in vivo. J Clin Endocrinol Metab. (2013) 98:3068-79. doi: $10.1210 /$ jc. $2013-1715$

95. Sohel MM, Hoelker M, Noferesti SS, Salilew-Wondim D, Tholen E, Looft C, et al. Exosomal and non-exosomal transport of extra-cellular microRNAs in follicular fluid: implications for bovine oocyte developmental competence. PLoS ONE (2013) 8:e78505. doi: 10.1371/journal.pone.0078505

96. Burns G, Brooks K, Wildung M, Navakanitworakul R, Christenson LK, Spencer TE. Extracellular vesicles in luminal fluid of the ovine uterus. PLoS ONE (2014) 9:e90913. doi: 10.1371/journal.pone.0090913

97. Atay S, Gercel-Taylor C, Kesimer M, Taylor DD. Morphologic and proteomic characterization of exosomes released by cultured extravillous trophoblast cells. Exp Cell Res. (2011) 317:1192-202. doi: 10.1016/j.yexcr.2011.01.014

98. Rubinstein E, Ziyyat A, Prenant M, Wrobel E, Wolf JP, Levy S, et al. Reduced fertility of female mice lacking CD81. Dev Biol. (2006) 290:351-8. doi: 10.1016/j.ydbio.2005.11.031

99. Tanigawa M, Miyamoto K, Kobayashi S, Sato M, Akutsu H, Okabe M, et al. Possible involvement of CD81 in acrosome reaction of sperm in mice. $\mathrm{Mol}$ Reprod Dev. (2008) 75:150-5. doi: 10.1002/mrd.20709

100. Ohnami N, Nakamura A, Miyado M, Sato M, Kawano N, Yoshida K, et al. CD81 and CD9 work independently as extracellular components upon fusion of sperm and oocyte. Biol Open (2012) 1:640-7. doi: 10.1242/bio.20121420

101. Ng YH, Rome S, Jalabert A, Forterre A, Singh H, Hincks CL, et al. Endometrial exosomes/microvesicles in the uterine microenvironment: a new paradigm for embryo-endometrial crosstalk at implantation. PLoS ONE (2013) 8:e58502. doi: 10.1371/journal.pone.0058502

102. Burns GW, Brooks KE, O’Neil EV, Hagen DE, Behura SK, Spencer TE. Progesterone effects on extracellular vesicles in the sheep uterus. Biol Reprod. (2018) 98:612-22. doi: 10.1093/biolre/ioy011

103. Braundmeier AG, Dayger CA, Mehrotra P, Belton RJ Jr, Nowak RA. EMMPRIN is secreted by human uterine epithelial cells in microvesicles and stimulates metalloproteinase production by human uterine fibroblast cells. Reprod Sci. (2012) 19:1292-301. doi: 10.1177/1933719112450332

104. Burnett LA, Light MM, Mehrotra P, Nowak RA. Stimulation of GPR30 increases release of EMMPRIN-containing microvesicles in human uterine epithelial cells. J Clin Endocrinol Metab. (2012) 97:4613-22. doi: 10.1210/jc.2012-2098

105. Tannetta D, Dragovic R, Alyahyaei Z, Southcombe J. Extracellular vesicles and reproduction-promotion of successful pregnancy. Cell Mol Immunol. (2014) 11:548-63. doi: 10.1038/cmi.2014.42

106. Pallinger E, Bognar Z, Bodis J, Csabai T, Farkas N, Godony K, et al. A simple and rapid flow cytometry-based assay to identify a competent embryo prior to embryo transfer. Sci Rep. (2017) 6:39927. doi: 10.1038/srep39927

107. Giacomini E, Vago R, Sanchez AM, Podini P, Zarovni N, Murdica V, et al. Secretome of in vitro cultured human embryos contains extracellular vesicles that are uptaken by the maternal side. Sci Rep. (2017) 7:5210. doi: 10.1038/s41598-017-05549-w

108. Mellisho EA, Velásquez AE, Nuñez MJ, Cabezas JG, Cueto JA, Fader $\mathrm{C}$, et al. Identification and characteristics of extracellular vesicles from bovine blastocysts produced in vitro. PLoS ONE (2017) 12:e0178306. doi: 10.1371/journal.pone.0178306

109. Qu P, Qing S, Liu R, Qin H, Wang W, Qiao F, et al. Effects of embryo-derived exosomes on the development of bovine cloned embryos. PLoS ONE (2017). 12:e0174535. doi: 10.1371/journal.pone.0174535

110. Montecalvo A, Shufesky WJ, Stolz DB, Sullivan MG, Wang Z, Divito SJ, et al. Exosomes as a short-range mechanism to spread alloantigen between dendritic cells during T cell allorecognition. J Immunol. (2008) 180:3081-90. doi: 10.4049/jimmunol.180.5.3081

111. Raposo G, Nijman HW, Stoorvogel W, Liejendekker R, Harding CV, Melief CJ, et al. B lymphocytes secrete antigen-presenting vesicles. J Exp Med. (1996) 183:1161-72. doi: 10.1084/jem.183.3.1161

112. Nolte-'t Hoen EN, Buschow SI, Anderton SM, Stoorvogel W, Wauben MH. Activated T cells recruit exosomes secreted by dendritic cells via LFA-1. Blood (2009) 113:1977-81. doi: 10.1182/blood-2008-08-174094

113. Zitvogel L, Regnault A, Lozier A, Wolfers J, Flament C, Tenza D, et al. Eradication of established murine tumors using a novel cell-free vaccine: dendritic cell-derived exosomes. Nat Med. (1998) 4:594-600. doi: 10.1038/nm0598-594

114. Admyre C, Bohle B, Johansson SM, Focke-Tejkl M, Valenta R, Scheynius A, et al. B cell-derived exosomes can present allergen peptides and activate allergen-specific $\mathrm{T}$ cells to proliferate and produce TH2-like cytokines. $J$ Allergy Clin Immunol. (2007) 120:1418-24. doi: 10.1016/j.jaci.2007.06.040

115. Wakim LM, Bevan MJ. Cross-dressed dendritic cells drive memory CD8+ T-cell activation after viral infection. Nature (2011) 471:629-32. doi: 10.1038/nature09863

116. MacKenzie A, Wilson HL, Kiss-Toth E, Dower SK, North RA, Surprenant A. Rapid secretion of interleukin-1beta by microvesicle shedding. Immunity (2001) 15:825-35. doi: 10.1016/S1074-7613(01)00229-1

117. Pizzirani C, Ferrari D, Chiozzi P, Adinolfi E, Sandonà D, Savaglio E, et al. Stimulation of P2 receptors causes release of IL-1beta-loaded microvesicles from human dendritic cells. Blood (2007) 109:3856-64. doi: 10.1182/blood-2005-06-031377

118. Qu Y, Franchi L, Nunez G, Dubyak GR. Nonclassical IL-1 beta secretion stimulated by P2X7 receptors is dependent on inflammasome activation and correlated with exosome release in murine macrophages. J Immunol. (2007) 179:1913-25. doi: 10.4049/jimmunol.179.3.1913

119. Xiang X, Liu Y, Zhuang X, Zhang S, Michalek S, Taylor DD, et al. TLR2mediated expansion of MDSCs is dependent on the source of tumor exosomes. Am J Pathol. (2010) 177:1606-10. doi: 10.2353/ajpath.2010. 100245

120. Chalmin F, Ladoire S, Mignot G, Vincent J, Bruchard M, Remy-Martin JP, et al. Membrane-associated Hsp72 from tumor-derived exosomes mediates STAT3-dependent immunosuppressive function of mouse and human myeloid-derived suppressor cells. J Clin Invest. (2010) 120:457-71. doi: 10.1172/JCI40483

121. Liu Y, Xiang X, Zhuang X, Zhang S, Liu C, Cheng Z, et al. Contribution of MyD88 to the tumor exosome-mediated induction of myeloid derived suppressor cells. Am J Pathol. (2010) 176:2490-9. doi: 10.2353/ajpath.2010.090777

122. Pap E, Pallinger E, Falus A, Kiss AA, Kittel A, Kovacs P, et al. T lymphocytes are targets for platelet- and trophoblast-derived microvesicles during pregnancy. Placenta (2008) 29:826-32. doi: 10.1016/j.placenta.2008.06.006

123. Atay S, Gercel-Taylor C, Suttles J, Mor G, Taylor DD. Trophoblast derived exosomes mediate monocyte recruitment and differentiation. Am J Reprod Immunol. (2011) 65:65-77. doi: 10.1111/j.1600-0897.2010.00880.x

124. Atay S, Gercel-Taylor C, Taylor DD. Human trophoblast-derived exosomal fibronectin induces pro-inflammatory IL-1beta production by macrophages. Am J Reprod Immunol. (2011) 66:259-69. doi: 10.1111/j.1600-0897.2011.00995.x

125. Pallinger E, Bognar Z, Bogdan A, Csabai T, Abraham H, SzekeresBartho J. PIBF+ extracellular vesicles from mouse embryos affect IL-10 production by CD8+ cells. Sci Rep. (2018) 8:4662. doi: 10.1038/s41598-01823112-z

126. Sun J, Madan R, Karp CL, Braciale TJ. Effector $\mathrm{T}$ cells control lung inflammation during acute influenza virus infection by producing IL-10 Nature Medicine (2009) 15:277-84. doi: 10.1038/nm.1929

127. Abel M, Sène D, Pol S, Bourlière M, Poynard T, Charlotte F, et al. Intrahepatic virus-specific IL-10-producing CD8 T cells prevent liver damage during chronic hepatitis C virus infection. Hepatology (2006) 44:1607-16. doi: 10.1002/hep. 21438

Conflict of Interest Statement: The authors declare that the research was conducted in the absence of any commercial or financial relationships that could be construed as a potential conflict of interest.

The handling editor is currently co-organizing a Research Topic with one of the authors JS-B and confirms the absence of any other collaboration.

Copyright (C) 2018 Szekeres-Bartho, Šućurović and Mulac-Jeričević. This is an openaccess article distributed under the terms of the Creative Commons Attribution License (CC BY). The use, distribution or reproduction in other forums is permitted, provided the original author(s) and the copyright owner(s) are credited and that the original publication in this journal is cited, in accordance with accepted academic practice. No use, distribution or reproduction is permitted which does not comply with these terms. 